\title{
Conversion efficiency of photosynthetically active radiation intercepted in biomass in stands of black wattle in Brazil
}

\author{
Eficiencia de conversión de la radiación fotosintéticamente activa interceptada \\ en biomasa en rodales de acacia negra en Brasil
}

\author{
Alexandre Behling a*, Carlos Roberto Sanquetta a, Ana Paula Dalla Corte a, Braulio Caron b, \\ Augusto Arlindo Simon ${ }^{c}$, Marcos Behling ${ }^{c}$, Denise Schmidt ${ }^{b}$ \\ * Corresponding author: ${ }^{\text {a }}$ Universidade Federal do Paraná, Centro de Ciências Florestais e da Madeira, Centro de excelência em \\ pesquisas sobre fixação de carbono na biomassa (BIOFIX), Av. Pref. Lothário Meissner, 900, Jardim Botânico, \\ Campus III 80210, 170, Curitiba, Paraná, Brasil, phone: (55) 41 3360-4264, alexandre.behling@yahoo.com.br \\ ${ }^{\mathrm{b}}$ Universidade Federal de Santa Maria, Agronomy Department, Frederico Westphalen, Brazil. \\ ${ }^{\mathrm{c}}$ TANAC S.A., Forestry Department, Montenegro, Brazil.
}

\begin{abstract}
SUMMARY
Biomass yield is a function of the conversion efficiency of photosynthetically active radiation intercepted in photoassimilates and varies depending on the conditions in which a plant is grown. Thus, this study sought to quantify the conversion efficiency of solar radiation intercepted by photosynthetically active biomass ( $\varepsilon b)$ in black wattle stands (Acacia mearnsii De Wild.). A study was therefore conducted in 1-7 year-old stands of the species in two sites (to span one plantation cycle), in which intercepted photosynthetically active radiation (PARi), leaf area index, light extinction coefficient and biomass yield were determined. A system of equations is proposed, therefore, as photosynthetic radiation is intercepted and assimilates are converted, the system of equations estimates biomass yield, and at the same time predicts the biomass partition within the tree. The biomass yield of black wattle was linearly related to PARi and the $\varepsilon b$ of the total biomass of black wattle is $0.0021 \mathrm{~kg} \mathrm{MJ}^{-1}$.
\end{abstract}

Key words: leaf area index, light extinction coefficient, photosynthetically active radiation, biomass compartments.

\section{RESUMEN}

El rendimiento en biomasa es una función de la eficiencia de conversión de radiación fotosintéticamente activa interceptada en fotoasimilados y varía, dependiendo de las condiciones en que se cultiva una planta. Este estudio cuantificó la eficiencia de conversión de la radiación solar interceptada por la biomasa fotosintéticamente activa (cb) en rodales acacia negra (Acacia mearnsii). Se realizó un estudio en rodales de 1-7 años de edad en dos sitios (para abarcar el ciclo completo de cultivo de la especie), en que se determinaron la radiación fotosintéticamente activa interceptada (PARI), el índice de área foliar, el coeficiente de extinción de la luz y el rendimiento de biomasa. Se propuso un sistema de ecuaciones que expresó como la radiación fotosintética es interceptada y los asimilados se convierten. El sistema de ecuaciones estima el rendimiento de biomasa y al mismo tiempo predice la partición de la biomasa dentro del árbol. El rendimiento en biomasa de acacia negra se relacionó linealmente con RFAi y la cb de la biomasa total de acacia negra fue $0,0021 \mathrm{~kg} \mathrm{MJ}^{-1}$.

Palabras clave: índice de área foliar, coeficiente de extinción de la luz, radiación fotosintéticamente activa, compartimentos de la biomasa.

\section{INTRODUCTION}

Plant growth is a function of the balance of biomass accumulated through photosynthesis. Thus, the dependence of photosynthetic processes on the environment is of interest to professionals working in the agricultural sciences, since plant productivity, and therefore crop yield, is dependent on rates of photosynthesis in that environment (Taiz and Zeiger 2004).

In this sense, the biomass yield of a plant depends on the quantity of photosynthetically active radiation absor- bed through the leaves and the efficiency with which it can convert radiant energy into assimilates through the process of photosynthesis. In experiments with agricultural crops, Montheith $(1965,1972,1977)$ noted that given adequate amounts of water and nutrients in healthy plants, biomass yield is governed by the intercepted photosynthetically active radiation. This phenomenon was later observed in forest species by several researchers (Linder 1985, Cannel 1989, Landsberg et al.1997, Sinclair and Muchow 1999, Stape et al. 2008, Caron et al. 2012, Campoe et al. 2013, Caron et al. 2014, Sanquetta et al. 2014). Thus, photosynthetically 
active radiation intercepted that is converted into biomass reveals the efficiency $(\varepsilon b)$ of radiation use by the species.

The relationship between $\varepsilon b$ and biomass production has most often been shown to be linear in which the slope of the relationship determines the efficiency of the radiation use in producing biomass (Shibles and Weber 1966, Tollenar and Bruulsema 1988, Caron et al. 2012, 2014, Sanquetta et al. 2014).

The association proposed by Montheith between biomass yield and the amount of intercepted photosynthetically active radiation is one of the most simplified models to estimate growth and yield. It has formed the theoretical basis for ecophysiological models that take into account photosynthetically active radiation intercepted by leaves (Wang and Jarvis 1990, Landsberg and Waring 1997). It is highly important to studies related to forest ecophysiology (Binkley et al. 2004) and can be used in many applications.

The study hypothesis is based on the fact that the conversion efficiency of photosynthetically active solar radiation intercepted in biomass is constant for varied environment conditions. This study sought to determine the conversion efficiency of photosynthetically active solar radiation intercepted in biomass in a stand of black wattle (Acacia mearnsii De Wild.) in the state of Rio Grande do Sul, Brazil.

\section{METHODS}

To conduct this study we drew data from temporary plots installed in commercial plantations of black wattle in regions of high concentrations of the species in the state of Rio Grande do Sul, Brazil, in the municipalities of Cristal and Piratini. In each municipality stands were studied in an age sequence: one, three, five and seven years to represent the full cultivation cycle practiced by the foresters.

In the city of Cristal, central coordinates of stands are located at $30^{\circ} 55^{\prime} \mathrm{S}$ and $52^{\circ} 10^{\prime} \mathrm{W}$. In Piratini central coordinates of stands are located at $31^{\circ} 24$ ' $\mathrm{S}$ and $52^{\circ} 57^{\prime} \mathrm{W}$. Stands were planted using a $3 \times 1.5$ meter spacing $(2,222$ plants per hectare).

In each stand a North-facing slope was selected where one plot was demarcated in each of the upper, middle and bottom thirds of the slope. The size of the plots measured 9 $\mathrm{x} 16$ meters for the one-year old stands and 9 x 14 meters for all other ages, making four rows of 10 plants in each row.

The circumference at breast height was measured for every plant in the plots using measuring tape with millimeter graduations. The two trees presenting averages for this variable were selected in each plot to evaluate biomass and leaf area. In each plot photosynthetically active radiation incident on the ground was also evaluated.

The measurement of biomass was performed by tree compartment: wood from bole + bark, live and dead branches, leaves, and flowers + fruits; each of which was separated and weighed to determine wet weight using a digital scale (Portable Electronic Scale) with an accuracy of 0.5 grams.
To determine dry biomass, samples of approximately 200 grams were collected including live and dead branches, leaves and flowers + fruits, which were immediately weighed to determine wet weight. For the bole, five discs, each $2 \mathrm{~cm}$ thick were removed at $0 \%, 25 \%, 50 \%, 75 \%$ and $100 \%$ of the commercial height ( $4 \mathrm{~cm}$ was assumed for top diameter). These samples were dried in a convection and injection oven at $75{ }^{\circ} \mathrm{C}$. After verifying that a constant mass had been reached, the material was weighed again to obtain moisture content and consequently the dry biomass using the expression:

$$
\mathrm{Bi}=\frac{\mathrm{WW}_{\mathrm{i}} * \mathrm{DW}_{i}}{\mathrm{WWs}_{\mathrm{i}}}
$$

\section{Where:}

$\mathrm{Bi}=$ dry biomass of a given component in $\mathrm{kg}$;

$\mathrm{WW}_{\mathrm{i}}=$ wet weight of a given component in $\mathrm{kg}$;

$\mathrm{DW}_{\mathrm{i}}=$ dry weight of the sample in $\mathrm{kg}$;

$\mathrm{WWs}_{\mathrm{i}}=$ wet weight of the sample in $\mathrm{kg}$.

Total biomass was determined by taking the sum of the dry biomass of all compartments (bole $=$ wood + bark, live and dead branches, leaves and flowers + fruits).

To determine leaf area three 50 grams samples were taken from the tree canopy. The leaflets were separated from the petiole and rakus and spread flat with an ironing board heated to $65^{\circ} \mathrm{C}$. Leaf area was determined using an integrator (3000 Canopy Analyser Li-Cor). At the end of the process all material (petiole, rakus and leaflet) was dried in a convection and injection oven at $65^{\circ} \mathrm{C}$. When a constant mass was reached, materials were weighed on an analytical balance. Thus, the leaf area of the plant was calculated by the expression:

$$
\mathrm{LA}=\frac{\mathrm{LB}^{*} \mathrm{LA}_{\mathrm{a}}}{\mathrm{DB}_{\mathrm{a}}}
$$

Where:

$\mathrm{LA}=$ leaf area in $\mathrm{m}^{2}$;

$\mathrm{LB}=$ leaf biomass in $\mathrm{kg}$;

$\mathrm{LA}_{\mathrm{a}}=$ leaf area of the sample in $\mathrm{m}^{2}$;

$\mathrm{DB}_{\mathrm{a}}=$ dry weight of leaf sample in $\mathrm{kg}$.

Evaluating photosynthetically active radiation (PAR) consisted on taking 225 readings using a piranometer (LICOR1600) during the day (7:30 am, 9 am, $12 \mathrm{pm}, 3 \mathrm{pm}$, $4: 30 \mathrm{pm}$ ) inside the stand in each age group and in each region for a total of 450 measurements for each age group.

Evaluation points were installed systematically within each plot in three orientations: one located in the planting row (1), another in between the planting rows (2) and a third at a $45^{\circ}$ angle between points 1 and 2. For each orientation in the evaluation, five stakes were fixed in the 
ground ( $28 \mathrm{~cm}$ in height from the ground level) and $75 \mathrm{~cm}$ from each other. The first stake was planted $38 \mathrm{~cm}$ from the tree with average diameter in the plot.

Measurement readings were taken inside the stand 30 centimeter in height from the ground surface, while readings outside the stand, namely the PARs incident on the stand, were carried out in the open in five measurements before and five measurements after each evaluation within the stand (according to the time of measurement).

Solar insolation times were obtained from INMET (National Institute of Meteorology - Brazil) at the Pelotas Weather Forecast Station. This was the closest station to the study site during the research period, located about $85 \mathrm{~km}$ from the municipality of Cristal and $70 \mathrm{~km}$ from Piratini. Global incident radiation was estimated using Angstrom's equation and modified by Prescot and Penman following the mathematical advancement described by Vianello and Alves (2000) and with coefficients fitted for the municipality of Pelotas by Steinmetz et al. (1999).

Biomass production was studied based on the model proposed by Monteith (1977), where this is a variable dependent on the amount of intercepted photosynthetically active radiation multiplied by the conversion efficiency $(\varepsilon b)$ of this radiation into biomass produced. Thus, $\varepsilon b$ can be calculated from the ratio of the average biomass yield to the cumulative intercepted photosynthetically active radiation involved, i.e.:

$$
\mathrm{B}=\varepsilon b^{*} \mathrm{PARi}
$$

Where:

$\mathrm{B}=$ dry biomass in $\mathrm{kg} \mathrm{m}^{-2}$;

PARi $=$ intercepted photosynthetically active radiation in MJ $\mathrm{m}^{-2}$;

$\varepsilon b=$ conversion efficiency of PARi in biomass produced in $\mathrm{kg} \mathrm{MJ}^{-1}$.

Estimation of accumulated photosynthetically active radiation was calculated based on the model proposed by Varlet-Grancher et al. (1989):

$$
\text { PARi }=0.95 *(\text { PARinc }) *\left(1-\mathrm{e}\left(-\mathrm{k}^{*} \mathrm{LAI}\right)\right)
$$

Where:

PAR $i=$ intercepted photosynthetically active radiation in $\mathrm{MJ} \mathrm{m}{ }^{-2}$;

$\mathrm{K}=$ coefficient of light extinction, dimensionless;

LAI $=$ leaf area index, dimensionless;

PARinc $=$ photosynthetically active radiation in $\mathrm{MJ} \mathrm{m}^{-2}$.

The leaf area index (LAI) was calculated as the ratio of the average leaf area per plot to the plantation spacing, i.e.:

$$
\mathrm{LAI}=\frac{\mathrm{LA}}{\mathrm{SAU}}
$$

Where:

$\mathrm{LAI}=$ leaf area index, dimensionless;

$\mathrm{LA}=$ mean leaf area of two plants measured per plot in $\mathrm{m}^{2}$; $\mathrm{SAU}=$ area of soil utilized by the plant, or the plantation spacing in $\mathrm{m}^{2}$.

The light extinction coefficient was calculated from Beer's law, which states that as sunlight passes through the various juxtaposed leaf layers in the canopy, the light intensity decreases exponentially as the level vegetation cover increases. Thus, the average extinction coefficient $(\mathrm{K})$ was obtained by:

$$
\mathrm{K}=-\frac{\ln \left(\frac{\text { PARt }}{\text { PAR }}\right)}{\text { LAI }}
$$

Where:

$\mathrm{K}=$ light extinction coefficient, dimensionless;

PARt $=$ PAR transmitted through the canopy that reaches the soil surface, in $\mu$ moles $\mathrm{s}^{-1} \mathrm{~m}^{-2}$;

PAR $\mathrm{i}=$ PAR incident on the stand, in $\mu$ moles $\mathrm{s}^{-1} \mathrm{~m}^{-2}$;

$\mathrm{LAI}=$ leaf area index, dimensionless; and

$\mathrm{Ln}=$ natural logarithm.

The fraction of photosynthetically active radiation was estimated to be $45 \%$ of the incident solar radiation. This fraction represents the average of those found in Rio Grande do Sul by Assis and Mendez (1989) and Pandolfo (1995). The estimation of accumulated photosynthetically active radiation was based on Monteith (1977) and VarletGrancher et al. (1989).

The ratio of intercepted photosynthetically active radiation to biomass yield was determined by a Pearson correlation analysis, which in turn was qualitatively evaluated regarding intensity using the criteria proposed by Callegari-Jacques (2003).

Values for conversion efficiency were calculated in terms of total biomass for each compartment and for each planting site. To verify whether the relationship between biomass yield (total and per compartment) and photosynthetically active radiation intercepted was the same for all planting sites, an analysis of covariance was performed.

The analysis of covariance (Snedecor method) revealed the need to use separate functions for each planting site, i.e., to test the hypothesis of line slope. If the difference is not significant for the slope, a regression can be fitted. The levels test was not performed, since the aim was to verify only the slope, as it determines the value of the conversion efficiency of intercepted photosynthetically active radiation into biomass.

The values of $\varepsilon b$ were obtained through the least squares method initially using independent fit (fit for total biomass and individually for each compartment) and also by simultaneously fit, i.e., $\varepsilon b$ was calculated for each compartment at once by a system of equations. Thus, $\varepsilon b$ for total biomass 
was considered to be the sum of the functions used for the other compartments. The simultaneous fitting methodology used was based on a work by Parresol et al. (2001).

\section{RESULTS}

The incidence of solar radiation averaged $14.49 \mathrm{MJ} \mathrm{m}^{-2}$ day $^{-1}$, ranging from 3.28 to $28.63 \mathrm{MJ} \mathrm{m}^{-2}$ day $^{-1}$. In general, solar radiation had the highest values in the first and last month of the year (summer season) and diminishing during June and July (winter season). A similar result was also found by Bergamaschi et al. (2003) for the municipality of Eldorado do Sul and Cargnelutti Filho et al. (2004) in other municipalities in the state of Rio Grande do Sul. According to these authors, these conditions are the result of the summer solstice which occurs in the latter half of December, with gradual reduction in insolation and increased solar declination until the winter solstice, in the latter half of June.

The average LAI was 5.35 with a confidence interval ranging from 4.63 to 6.07 . The minimum observed value was 3.25 and the maximum was 9.10 , with a coefficient of variation of $31.80 \%$. The mean light extinction coefficient $(\mathrm{K})$ was 0.28 , with a confidence interval ranging from 0.26 to 0.29 . The coefficient of variation was $13.07 \%$, with a minimum value of 0.21 and a maximum of 0.33 .

Biomass yield showed a positive linear relationship with the intercepted photosynthetically active radiation, and was very strongly correlated $(93.81 \%)$. Similar conversion efficiency $(\varepsilon b)$ values of the total biomass regarding the amount of accumulated photosynthetically active radiation intercepted were found between the two environments: $0.0021 \mathrm{~kg} \mathrm{MJ}^{-1}$ in stands grown in the municipality of Cristal: Southeast Slope and $0.0022 \mathrm{~kg} \mathrm{MJ}^{-1}$ in stands grown in the municipality of Piratini, Southeast Range. The covariance analysis applied to the independent equations between the two plantation sites showed no difference among the efficiency values (table 1 ). The value of $\varepsilon b$ for the total biomass of black wattle is $0.0021 \mathrm{~kg} \mathrm{MJ}^{-1}$.
The solar energy efficiency in black wattle trees was also calculated for each biomass compartment $($ bole $=$ wood and bark, leaves, branches - live and dead and flowers + fruits). The analysis of covariance applied to the independent equations (table 1) revealed that for the same compartment, the slopes did not differ among plantation sites (Southeast Slope, Cristal and Southeast Range, Piratini).

Results of the fit of independent models were not satisfactory, given that the sum of the $\varepsilon b$ biomass of each compartment must be compatible with the $\varepsilon b$ of the total biomass (figure 1A). The incompatibility caused by independent fitting was resolved by fitting a system of equations (or simultaneous fitting) (figure 1B).

Thus, the conversion efficiency ( $(\mathrm{b})$ of bole biomass (wood and bark) in relation to the amount of accumulated photosynthetically active radiation intercepted was $0.001695 \mathrm{~kg} \mathrm{MJ}^{-1}$ for bole biomass, $0.000266 \mathrm{~kg} \mathrm{MJ}^{-1}$ for branches, $0.000063 \mathrm{~kg} \mathrm{MJ}^{-1}$ for leaves and $0.000018 \mathrm{~kg}$ $\mathrm{MJ}^{-1}$ for flowers and fruits.

In plantation forests, the most important product is bole biomass; hence a system of equations that takes into account the total biomass of bole and consequently the canopy would seem appropriate, as it simplifies the responses of higher importance. Thus, the $\varepsilon b$ conversion values for total biomass and for the bole remained the same $\left(0.0021 \mathrm{~kg} \mathrm{MJ}^{-1}\right.$ and $0.0017 \mathrm{~kg} \mathrm{MJ}^{-1}$, respectively) whereas the canopy value was $0.0004 \mathrm{~kg} \mathrm{MJ}^{-1}$ (figure 2).

The ratio of the slopes for bole biomass was $80.95 \%$ and $19.05 \%$ for the canopy. If total biomass yield given in a rotation age, i.e., at age seven, is considered, the partition was $81.96 \%$ for the bole and $18.04 \%$ for the canopy. Thus coefficient proportion results are consistent with the observed partition of biomass at the end of the rotation. However, it is important to note that for each point along the estimate line, biomass partition ratios equivalent to observed ones will be generated. This is as a consequence of the different slopes and the compatibility of the system of equations.

Table 1. Analysis of covariance of conversion efficiency of intercepted photosynthetically active radiation into biomass obtained in stands of black wattle.

Análisis de covarianza de la eficiencia de conversión de la radiación fotosintéticamente activa interceptada en biomasa obtenida en rodales de acacia negra.

\begin{tabular}{lccccc}
\hline Compartment & DF & MQ & F & $\alpha \mathrm{F}$ & Equality between the group \\
\hline Total & 1 & 18.9133 & 1.8532 & $24.51 \%$ & Yes \\
Bole & 1 & 6.2073 & 0.6082 & $47.90 \%$ & Yes \\
Branches & 1 & 40.1762 & 3.9366 & $11.82 \%$ & Yes \\
Leaves & 1 & 40.6438 & 3.9824 & $11.67 \%$ & Yes \\
Flowers and fruits & 1 & 40.8151 & 3.9992 & $11.61 \%$ & Yes \\
\hline
\end{tabular}



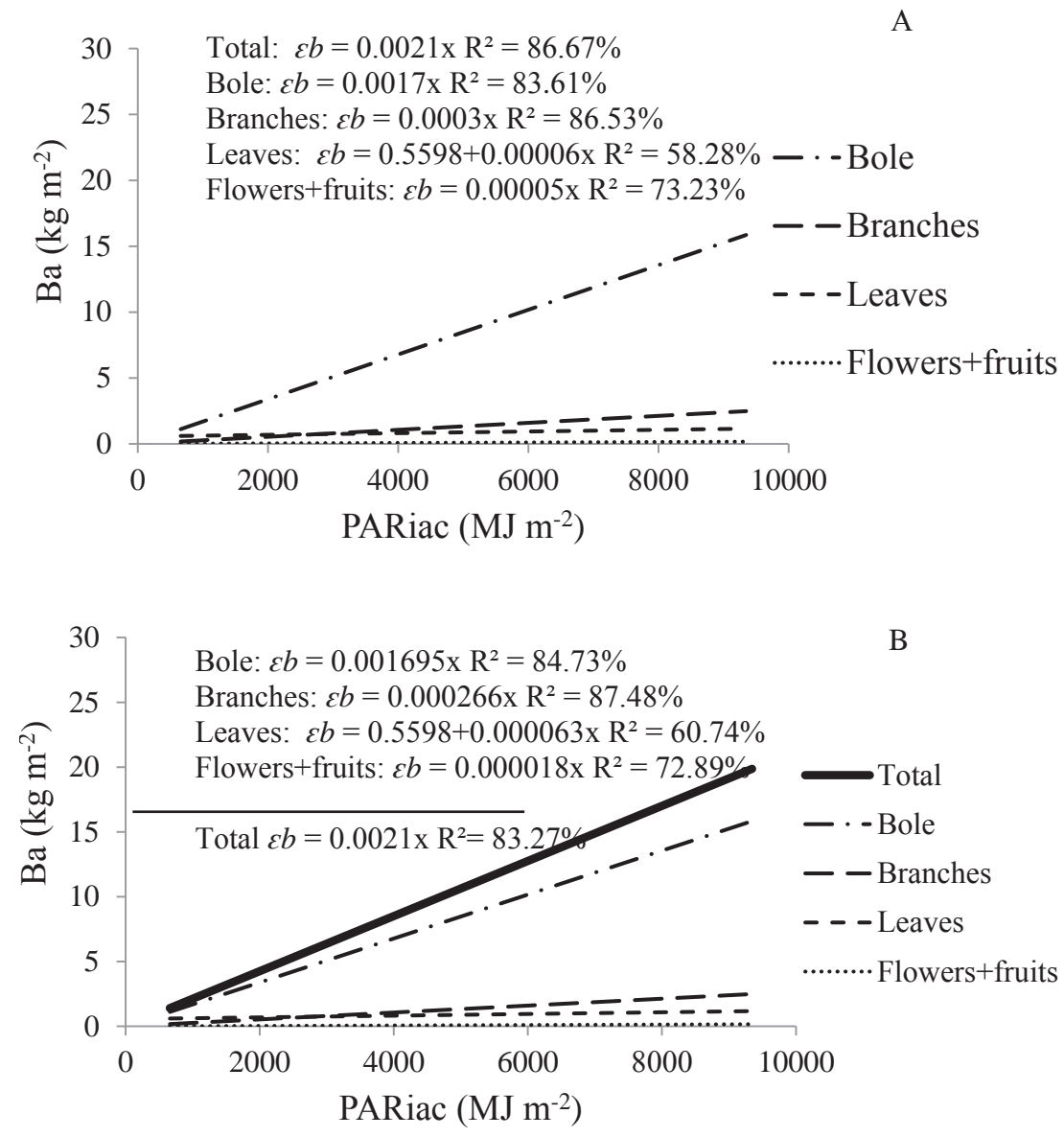

Figure 1. Conversion efficiency of intercepted photosynthetically active radiation in total biomass, bole, branches, leaves and flowers + fruits, obtained through independent fit (a) and simultaneous fit (b). Where: $\varepsilon b=$ Conversion efficiency of intercepted photosynthetically active radiation in biomass, $\mathrm{PARiac}=$ accumulated photosynthetically active radiation intercepted, and $\mathrm{Ba}=$ accumulated biomass.

Eficiencia de conversión de la radiación fotosintéticamente activa interceptada en biomasa total, tallo, rama, hojas y flores + frutas, obtenida a través de un ajuste independiente (a) y simultáneo (b). Donde: RFAiac = radiación fotosintéticamente activa interceptado acumulada y Ba = biomasa acumulada.

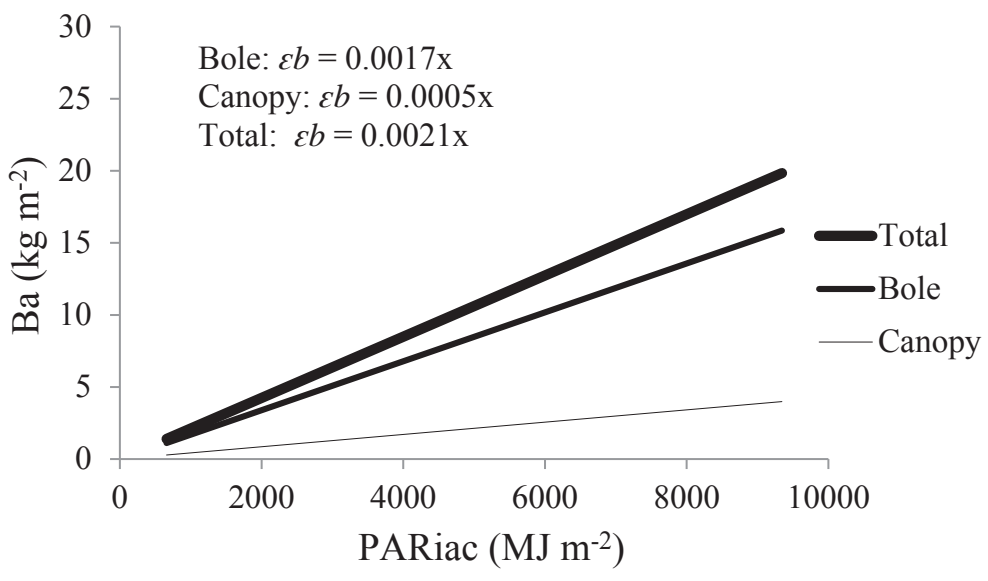

Figure 2. Conversion efficiency of intercepted photosynthetically active radiation in total biomass and canopy, obtained by simultaneous fit. Where: $\varepsilon b=$ Conversion efficiency of intercepted photosynthetically active radiation in biomass, PARiac $=$ accumulated photosynthetically active radiation intercepted and $\mathrm{Ba}=$ accumulated biomass.

Eficiencia de conversión de la radiación fotosintéticamente activa interceptada en biomasa total y la corona, obtenida mediante el ajuste simultáneo. Donde: RFAiac = radiación fotosintéticamente activa interceptada acumula y Ba = biomasa acumulada. 


\section{DISCUSSION}

Biomass yield showed a positive linear relationship with the intercepted photosynthetically active radiation. This trend was demonstrated as a linear function, and has been observed in other forest species by Landsberg et al. (1997), Kiniry (1998), Sinclair and Muchow (1999), Stape (2002), Stape et al. (2008), Caron et al. $(2012,2013)$ and Campoe et al. (2013).

The dry biomass yield $\left(\mathrm{B}, \mathrm{kg} \mathrm{m}^{-2}\right)$ for black wattle can be estimated from intercepted photosynthetically active radiation (PARi, in $\mathrm{MJ} \mathrm{m}^{-2}$ ) using the equation:

$$
\mathrm{B}=0.0021^{*} \mathrm{PARi}
$$

The fit resulted in a coefficient of determination of $86.67 \%$ and standard error in the estimate of $30.46 \%$. Stape (2002) applied the light use efficiency equations in eucalyptus plantations in Brazil and also found satisfactory results. By that same method, forest growth is proportional to the photosynthetically active radiation intercepted by the leaves, multiplied by the conversion efficiency (Binkley et al. 1994).

The examples of conversion efficiency studies in forest species in the international literature greatly outnumber the examples in Brazilian literature. This observation underscores the importance of intensifying research on sunlight use, since growth and yield of black wattle and other forest species depend on the amount of radiation in- tercepted and photosynthetic conversion efficiency of this energy into biomass.

The conversion efficiency values of photosynthetically active radiation in biomass in black wattle plantations were higher than those observed by Linder (1985), Wang et al. (1991), Saldarriaga and Luxmoore (1991), Landsberg and Hingston (1996), Landsberg et al. (1997), Kiniry (1998), McCrady and Jokela (1998), Mariscal et al. (2000) and Campoe et al. (2013) (table 2).

Based on a work published in Brazilian literature, the conversion efficiency of black wattle was lower in yerba mate plantations (Ilex paraguariensis A. St. Hil.) according to Caron et al. (2013) $\left(0.83 \mathrm{~g} \mathrm{MJ}^{-1}\right.$ in a system of intercropping with Pinus elliottii Engelm and still lower in a single-species system, $0.23 \mathrm{~g} \mathrm{MJ}^{-1}$ ) in seedlings of Eucalyptus grandis W. Hill ex Maiden (3.7 to $7.76 \mathrm{~g} \mathrm{MJ}^{-1}$ ).

Sinclair and Muchow (1999) emphasize that the conversion efficiency is the result of several intrinsic and extrinsic factors, among them: species, the photosynthetic process, gas exchange, nutrient concentration in the leaves (especially nitrogen), soil resources, atmospheric vapor pressure deficit, air temperature and solar radiation. Works by Warren and Adams (2001), Close (2004) and Stape, Ryan and Binkley (2004) demonstrated that photosynthetic capacity is directly related to nitrogen concentration in the leaves.

In terms of nitrogen uptake, black wattle has the advantage of an association with bacteria of the genus Rhizobium which fix atmospheric nitrogen in the soil (estimated at $200 \mathrm{~kg} \mathrm{ha}^{-1}$ year $^{-1}$ as per Salas, 1987), thus removing this

Table 2. Conversion efficiency of intercepted photosynthetically active radiation into biomass for several species.

Eficiencia de la conversión de la radiación fotosintéticamente activa interceptada en biomasa para varias especies.

\begin{tabular}{lcl}
\hline \multicolumn{1}{c}{ Species } & $\varepsilon \mathrm{b}\left(\mathrm{g} \mathrm{MJ} \mathrm{J}^{-1}\right)$ & \multicolumn{1}{c}{ Author } \\
\hline Eucalyptus sp. & $\sim 1.00$ & Linder (1985) \\
Pseudotsuga menziesii & $\sim 1.90$ & Wang et al. (1991) \\
Amazon forest up to 10 years old (successional stage) & 0.23 & Saldarriaga and Luxmoore (1991) \\
Amazon forest up to 50 years old (successional stage) & 0.07 & Saldarriaga and Luxmoore (1991) \\
Olea europaea L. & 1.35 & Mariscal et al. (2000) \\
Crops & 2.80 & Landsberg et al. (1997) \\
Rain forests & 0.20 & Landsberg et al. (1997) \\
Other forests & 1 to 2 & Landsberg et al. (1997) \\
Juniperus virginiana L. & 1.60 & Kiniry (1998) \\
Prosopis glandulosa var. glandulosa Torr. & 1.61 & Kiniry (1998) \\
Pinus taeda L. & $1.33-1.48$ & McCrady and Jokela (1998) \\
Eucalyptus globulus Labill. & 0.93 to 2.23 & Landsberg and Hingston (1996) \\
Eucalyptus grandis W.Hill ex Maiden. & 0.67 & Henskens (2001) \\
Acacia mearnsii De Wild. & 0.75 to 1.03 & Campoe et al. (2013) \\
\hline
\end{tabular}


element from among the limiting growth factors. Binkley and Giardina (1997) emphasize that tree legumes accumulate nitrogen in their biomass more readily due to this fixation capacity, supplying between $40 \%$ and $80 \%$ of the nitrogen used by these trees. Therefore, nitrogen concentration in the leaves of black wattle is expected to be higher than in leaves of species in which conversion efficiencies were compared. This finding corroborates reports of the highest conversion efficiency values obtained, since according to Evans (1989), Dewar (1996), Landsberg and Gower (1997), Green et al. (2003) and Dewar (2012), the nitrogen content in canopy affects rates of photosynthesis and hence forest productivity.

The solar energy efficiency in black wattle trees was also calculated for each biomass compartment $($ bole $=$ wood and bark, leaves, branches - live and dead and flowers + fruits). Conversion efficiency of leaf biomass was represented by a model different from that used for the other compartments; one which represents not only a slope but also a significant intercept. This means that at the outset of stand establishment, biomass yield in leaves is prioritized to increase photosynthetic area and intercept more light, which is converted into assimilates and distributed to other tissues. Kozlowski et al. (1991) report that the proportion between the biomass compartments varies with tree age, and this is due to changes in the partition of assimilates as the plant grows. In young trees, the distribution is prioritized for canopy formation, while with increasing age the trunk is prioritized, a pattern also observed in the biomass partition of the black wattle (figure 3).

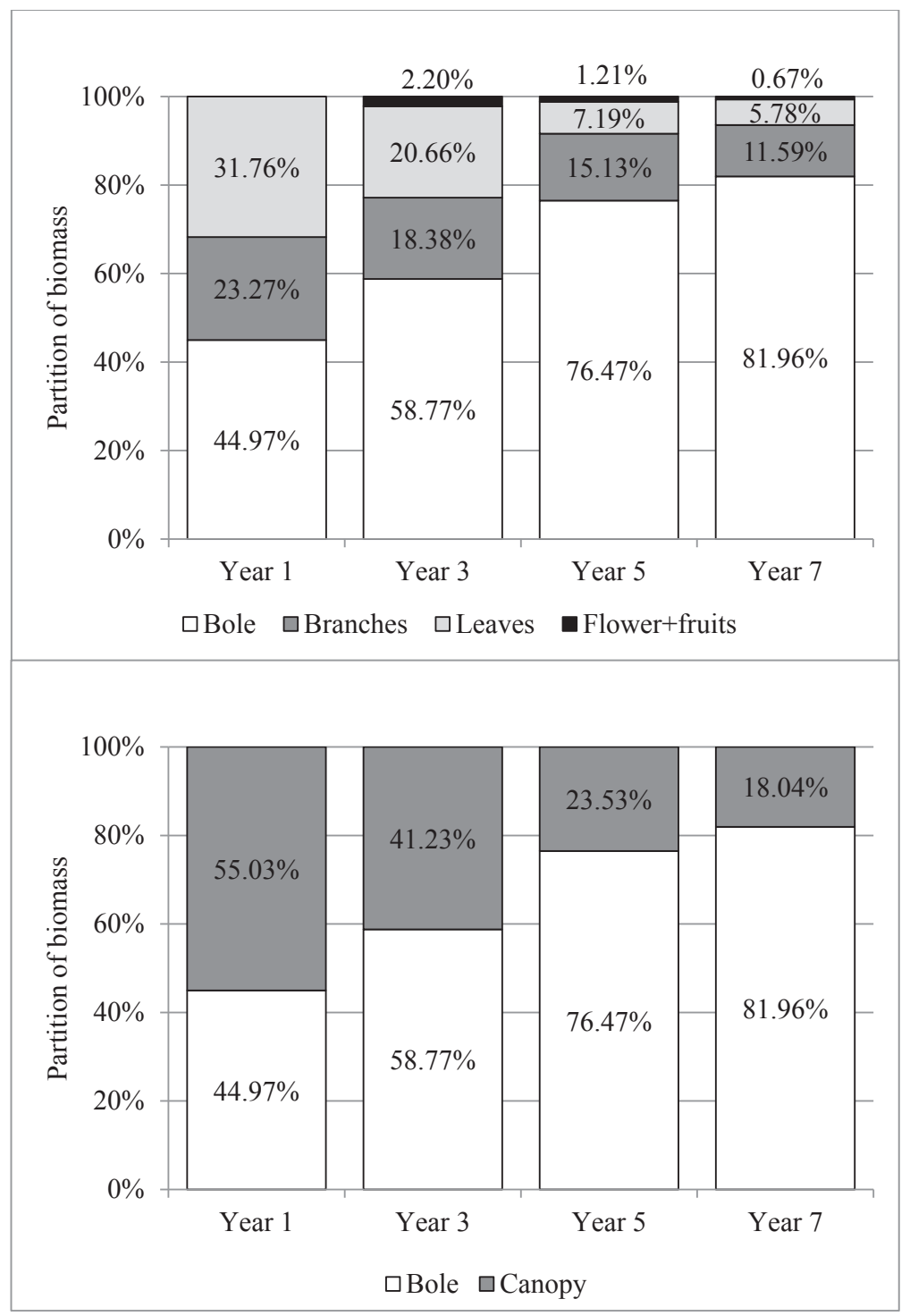

Figure 3. Partition of biomass throughout the growing cycle in stands of black wattle.

Partición de la biomasa a lo largo del ciclo de cultivo del acacia negra. 
The use of simultaneous fitting was adequate for establishing the conversion efficiency values of photosynthetically active radiation in biomass per compartment. For total biomass the simultaneous fit resulted in $\varepsilon b$ value of 0.0021 $\mathrm{kg} \mathrm{MJ}^{-1}$; the same as that obtained by independent fitting. However, $\varepsilon b$ values in all biomass compartments, namely bole, leaves, branches and flowers + fruits, underwent minor changes and at a point that made the whole system compatible. Conversion efficiency values are shown in figure 2. Thus, the estimate can be performed for each compartment, and simultaneously for all compartments, since the simultaneous fit guarantees overall quality. That is, the sum of equations for each compartment is the same as the result from the equation for total biomass. This condition is adequate and was also presented by Parresol et al. (2001).

Moreover, this situation is also suitable for determining conversion efficiency values, since as photosynthetic radiation is intercepted and assimilates are converted, the system of equations estimates biomass yield, and at the same time predicts the biomass partition within the tree. It is a fact that throughout the growth cycle, biomass partition is not uniform in the compartments (figure 3 ). However, these differences are intrinsically modeled concerning the slope values obtained. Therefore, the estimated proportions along the line are induced by two factors: different slopes among the compartments and the compatibility of biomass estimates generated by the simultaneous fit. This same situation applies to the system of equations that takes into account the total biomass, bole and canopy.

\section{CONCLUSIONS}

The $\varepsilon b$ for the total biomass of black wattle is 0.0021 $\mathrm{kg} \mathrm{MJ}^{-1}$.

The use of simultaneous fitting is adequate for establishing the conversion efficiency values of photosynthetically active radiation in biomass per compartment.

The $\varepsilon b$ is not influenced by planting location; hence the observed values are intrinsic to the species.

Biomass yield in black wattle is linearly related to the photosynthetically active radiation intercepted.

\section{ACKNOWLEDGEMENTS}

The authors thank TANAGRO S.A. Company, the Agroclimatology Laboratory of Federal University of Santa Maria and the Research Excellency Center for Carbon Sink in Biomass for the collaboration in this research and also CNPq for granting a scholarship at master degree level for Alexandre Behling.

\section{REFERENCES}

Assis FN, MEG Mendez. 1989. Relação entre radiação fotossinteticamente ativa e radiação global. Pesquisa Agropecuária Brasileira 2(7): 797-800.
Bergamaschi H, MR Guadagnin, LS Cardoso, MIG Silva. 2003. Clima da Estação Experimental da UFRGS e região de abrangência. Porto Alegre, Brasil. UFRGS. 78 p.

Binkley D, JRK Cromack, D BAKER. 1994. Nitrogen fixation by red alder: biology, rates, and controls. In: Hibbs D, DD DeBell, RF Tarrant eds. Biology and management of red alder. Corvallis, United State of America. Oregon State University Press. p. 57-72.

Binkley D, JL Stape, MG Ryan. 2004. Thinking about efficiency of resource use in forests. Forest Ecologic and Management 193: 5-16.

Binkley D, C Giardina. 1997. Biological nitrogen fixation in plantations. In Nambiar EKS, A Brown eds. Management of soil, water and nutrients in tropical plantation forests. Canberra, Australia. ACIAR. p. 297-337.

Callegari-Jacques SM. 2003. Bioestatística - Princípios e Aplicações. Porto Alegre, Brasil. Artmed. 207 p.

Cannell MGR. 1989. Light interception, light use efficiency and assimilate partitioning in poplar and willow stands. In Pereira JS, JJ Landsberg eds. Biomass production by fastgrowing tress. Dordrecht, The Netherlands. Kluwer Academic. p. 1-12.

Campoe OC. JL Stape, Y Nouvellon, JP Laclau, WL Bauerle, D Binkley, LE Guerric, GL Maire. 2013. Stem production, light absorption and light use efficiency between dominant and non-dominant trees of Eucalyptus grandis across a productivity gradient in Brazil. Forest Ecology and Management 288: 14-20.

Cargnelutti Filho A, R Matzenauer, JK Trindade. 2004. Ajustes de funções de distribuição de probabilidade à radiação solar global no Estado do Rio Grande do Sul. Pesquisa Agropecuária Brasileira 39(12): 1157-1166.

Caron BO, VQ Souza, PA Manfron, C Busanello, A Behling, E Eloy, R Bamberg. 2014. Eficiência do uso da radiação solar por plantas Ilex paraguariensis A. St. Hil. cultivadas sob sombreamento e a pleno sol. Ciência Florestal 24: 257-265.

Caron BO, VQ Souza, R Trevisan, D Schmidt, A Behling, R Bamberg, E Eloy. 2012. Eficiência de conversão da radiação fotossinteticamente ativa interceptada em fitomassa de mudas de eucalipto. Revista Árvore 36(5): 833-842.

Close DC. 2004. Within-canopy of nitrogen and photosynthetic activity of Eucalyptus nitens and Eucalyptus globulus in response to nitrogen nutrition. Australian Journal of Botanic 52: 133-140.

Dewar RC. 2003. Information theoretic explanation of maximum entropy production, the fluctuation theorem and self-organized criticality in non-equilibrium stationary states. Journal of Physics A: Mathematical and General 36: 631-641.

Dewar RC. 1996. The correlation between plant growth and intercepted radiation: an interpretation in terms of optimal plant nitrogen content. Annals of Botany 78: 125-136.

Evans JR. 1989. Photosynthesis and nitrogen relationships in leaves of C3 plants. Oecologia 78: 9-19, 1989.

Gower ST, CJ Kucharik, JM Norman. 1999. Direct and indirect estimation of leaf area index, fPAR and net primary production of terrestrial ecosystems. Remote Sensing of Environment 70: 29-51.

Green DS, JE Erickson, EL Kruguer. 2003. Foliar morphology and canopy nitrogen as predictors of light-use efficiency in terrestrial vegetation. Agricultural and Forest Meteorology 115: 163-171. 
Henskens FL, M Battaglia, ML Cherry, CL Beadle. 2001. Physiological basis of spacing effects on tree growth and form in Eucalyptus globulus. Trees 15: 365-377.

Kiniry JR. 1998. Biomass accumulation and radiation use efficiency of honey mesquite and eastern red cedar. Biomass and Bioenergy 15: 467-473.

Kozlowski TT, PJ Kramer, SG Pallardy. 1991. The physiological ecology of woody plants. New York, United State of America. Academic Press. 657 p.

Landsberg JJ. 1986. Physiological ecology of forest production. London, England. Academic Press. 198 p.

Landsberg JJ, ST Gower. 1997. Applications of physiological ecology to forest management. San Diego, United States of America. Academic Press. 354 p.

Landsberg JJ, FJ Hingston. 1996. Evaluating a simple radiation/ dry matter conversion model using data from Eucalyptus globulus plantations in Western Australia. Tree Physiology 16: 801-808.

Landsberg JJ, RH Waring. 1997. A generalized model of forest productivity using simplified concepts of radiation-use efficiency, carbon balance and partitioning. Forest Ecology and Management 95: 209-228.

Linder S. 1985. Potential and actual production in Australian forest stands. In Landsberg JJ, W Parsons eds. Research for Forest Management. Melbourne, Australia. CSIRO. p. 1135.

Mariscal MJ, F Orgaz, FJ Villalobos. 2000. Radiation-use efficiency and dry matter partitioning of a young olive (Olea europaea) orchard. Tree Physiology 20: 65-72.

McCrady RL, EJ Jokela. 1998. Canopy dynamics, light interception, and radiation use efficiency of selected loblolly pine families. Forest Science 44: 64-72.

Monteith JL. 1977. Climate and the efficiency of crop production in Britain. Proceedings of the Royal Society of London 281: 277-294.

Monteith JL. 1965. Light distribution and photosynthesis in field crops. Annals of Botany 29: 17-37.

Monteith JL. 1972. Solar radiation productivity in tropical ecosystems. Journal of Applied Ecology 9(3): 747-766.

Pandolfo C. 1995. Parâmetros básicos para uso na modelagem do rendimento de matéria seca de alfafa (Medicago sativa L.). Dissertação, mestrado em Agronomia. Porto Alegre, Brasil. Universidade Federal do Rio Grande do Sul. 128 p.

Parresol BR. 2001. Additividy of nonlinear biomass equations. Canadian Journal Forest Research 31(1): 865-878.

Salas G. 1987. Suelos y ecosistemas forestales. San José, Costa Rica. IICA. 447 p.

Saldarriaga JG, RJ Luxmoore. 1991. Solar energy conversion efficiencies during succession of a tropical rain forest in Amazonia. Journal of Tropical Ecology7: 233-242.

Sanquetta CR, A Behling, AP Dalla Corte, G Camacho Cadori, S Costa Junior, JH Pedrosa Macedo. 2014. Eficiência de conversão da radiação fotossintética interceptada em Fitomassa de mudas de Eucalyptus dunii Maiden em função da densidade de plantas e do ambiente de cultivo. Scientia Forestalis 42(104): 573-580.

Shibles RM, CR Weber. 1996. Interception of solar radiation and dry matter production by various soybean planting patterns. Crop Science 6(1): 55-59.

Sinclair TR, RC Muchow. 1999. Radiation use efficiency. Advances in Agronomy 65: 215-265.

Stape JL. 2002. Production ecology of clonal Eucalyptus plantations in northeastern Brazil. Thesis in Forest Sciences. Fort Collins, United States of America. Colorado State University. 225 p.

Stape JL, D Binkley, MG Ryan. 2008. Production and carbon allocation in a clonal Eucalyptus plantation with water and nutrient manipulations. Forest Ecology and Management 255: 920-930.

Stape JL, MG Ryan, D Binkley. 2004. Testing the utility of the 3-PG model for growth of Eucalyptus grandis x urophylla eith natural and manipulated supplies of water and nutrients. Forest Ecology and Management 193: 219-234.

Steinmetz S, FN Assis, WR Soares. 1999. Estimativa da radiação solar global a partir da insolação na região de Pelotas, Rio Grande do Sul. Agropecuária Clima Temperado 2(1): 77-85.

Taiz L, E Zeiger. 2004. Fisiologia vegetal. Porto Alegre, Brasil. Artmed. 719 p.

Tollenaar M, TW Bruulsema. 1988. Efficiency of maize dry matter production during periods of complete leaf area expansion. Agronomy Journal 80: 580-585.

Varlet-Grancher C, C Gosse, M Chartier, H Sinoquet, R Bonhomme, JM Allirand. 1989. Mise au point: rayonnement solaire absorbé ou intercepté par um couvert végétal. Agronomie 9: 419-439.

Vianello RL, AR Alves. 2000. Meteorologia Básica e Aplicações. Viçosa, Brasil. UFV. 448 p.

Wang YP, PG Jarvis. 1990. Description and validation of an array model - MAESTRO. Agricultural and Forest Meteorology5: 257-280.

Wang YP, PG Jarvis, CMA Taylor. 1991. PAR absorption and its relation to aboveground dry matter production of Sitka spruce. Journal of Applied Ecology 28: 547-560.

Warren CR, MA Adams. 2001. Distribution of N, Rubisco and photosynthesis in Pinus pinaster and acclimation to light. Plant, Cell and Environment 24: 597-609. 
